\title{
Electron microscopic microanalysis of bronchoalveolar lavage: a way to identify exposure to silica and silicate dust
}

\author{
E Monsó, A Carreres, J M Tura, J Ruiz, J Fiz, C Xaus, M Llatjós, J Morera
}

Serveis de

Pneumologia i

Anatomia Patoldgica,

Hospital Germans

Trias i Pujol,

Badalona, Spain, and

Laboratori de

Microscopia

Electrónica, ITQT,

Consell Superior

d'Investigacions

Cientifiques,

Barcelona, Catalonia,

Spain

E Monsó

A Carreres

J M Tura

J Ruiz

J Fiz

C Xaus

M Llatjós

J Morera

Correspondence to: Dr E Monsó, Servei de Pneumologia, Hospital Germans Trias i Pujol, Ap correus 72,08916 Badalona Catalonia, Spain.

Accepted 26 February 1997

\begin{abstract}
Objectives-The diagnostic implications of finding non-fibrous inorganic particles in bronchoalveolar lavage (BAL) fluid has not been fully assessed. The aim of this study has been to measure the silica and non-fibrous silicates in BAL fluid from populations with different exposures to inorganic dust, and to find whether such measurement is useful for diagnostic purposes.
\end{abstract}

Materials and methods-BAL samples from 19 subjects with only environmental exposure to inorganic dust (group A, mean (SD) age $50.7(15.2)$ ), 23 subjects with normal chest $x$ ray films exposed to silica or silicates at work (group B, mean (SD) age $52.0(12.4)$ ), and 15 subjects with a previous diagnosis of silicosis (group $\mathbf{C}$, mean (SD) age 68.0 (6.5)) were studied. Absolute and relative cell counts were found, and the samples were prepared for microanalysis by electron microscopy (EM). Firstly, semiquantitative $x$ ray microanalysis was performed to find the level of silicon (Si) (peak/background Si) and this was followed by microanalysis of individual particles by EM. Variables related to the level of Si detected were assessed with multivariate analysis.

Results-Detected levels were higher in group B $(2.09,95 \%$ confidence interval (95\% CI) 1.56 to 2.82$)$ and $C(1.50,95 \% \mathrm{CI}$ 1.07 to 2.12$)$ than in group $A(0.87,95 \%$ CI 0.66 to 1.16) ( $P<0.05$, Dunett $t$ test). A first multivariate analysis showed that exposure to silica or silicates was the only determinant of the level of Si expressed as $\log$ peak/background $\mathrm{Si}$, when adjusted for age, sex, smoking habit, and cell count. $A$ second multivariate analysis with microanalysis of individual particles as an independent variable showed the silica count to be the main predictor of detected concentration of Si. Silica and nonaluminium silicates together explain $55.5 \%\left(\mathbf{R}^{2}\right)$ of the variation in detected levels of Si.

Conclusions-Detected levels of Si in BAL fluid depend on silica count and are higher in subjects with exposure to inorganic dust at work, but will not discriminate between exposed subjects with and without silicosis. Because semiquantitative $x$ ray microanalysis does not accurately define exposure to non-silica inorganic particles, this measurement must be followed by EM microanalysis of individual particles in most cases, especially when exposure to silicates or metal dust is suspected.

Keywords: bronchoalveolar lavage; electron microscopy; pneumoconiosis

(Occup Environ Med 1997;54:560-565)

Inorganic dust content of lung tissue must sometimes be measured in patients who have been occupationally exposed to dust, mainly when the diagnosis remains unclear after the examination of clinical and radiological data. Light microscopy, whether on direct examination or after lung digestion, yields useful information on asbestiform bodies, ${ }^{1-3}$ but most non-fibrous inorganic particles will only be detected with electron microscopy (EM). Additional information on inorganic particles in lung tissue can be obtained with EM microanalysis, a complementary tool that can determine the elemental composition of the inorganic particles seen with EM. ${ }^{45}$

Bronchoalveolar lavage (BAL) is yet another technique for the study of the lower airways. This provides fluid samples representative of the cell content of the lower airways and is also useful for measuring asbestiform bodies and asbestos fibres, ${ }^{6-13}$ with a good correlation between BAL fluid and lung tissue asbestiform body counts. ${ }^{14} 15$ The non-fibrous inorganic particle content of BAL has been assessed with EM in populations exposed to dusty workplaces, ${ }^{16-18}$ in some cases with the complementary use of EM microanalysis to identify the elemental composition of the inorganic particles. $^{19-21}$

During the EM examination of a biological sample semiquantitative $x$ ray microanalysis (SXM) can also be performed. The SXM is a non-time-consuming approach to EM microanalysis that measures the various elements present in a sample, considering all the inorganic particles together, and has previously proved its usefulness to discriminate between silicosis and fibrosis not due to exposure to inorganic dust in samples of lung tissue $e^{22}$ and BAL. ${ }^{23}$ The SXM can be performed together with EM microanalysis of individual particles, which provides a more detailed description of the elemental composition of the inorganic particles present in the sample. In this study, SXM of BAL samples from subjects with 
Table 1 Group A environmental exposure

\begin{tabular}{lllll}
\hline $\begin{array}{l}\text { Patient } \\
\text { number }\end{array}$ & Age & $\begin{array}{l}\text { Tobacco } \\
\text { (pack-years) }\end{array}$ & Sex & Work \\
\hline A1 & 78 & 60 & M & Cattle raiser \\
A2 & 51 & 33 & M & Publicist \\
A3 & 59 & 32 & M & Office worker \\
A4 & 51 & 22 & W & Watchman \\
A5 & 30 & 0 & M & Teacher \\
A6 & 41 & 0 & F & Textile worker \\
A7 & 59 & 42 & M & Butcher \\
A8 & 67 & 33 & M & Textile worker \\
A9 & 35 & 18 & M & Butcher \\
A10 & 65 & 0 & M & Food seller \\
A11 & 53 & 36 & M & Office worker \\
A12 & 46 & 29 & M & Bookbinder \\
A13 & 49 & 32 & M & Driver \\
A14 & 22 & 0 & F & Cloth presser \\
A15 & 71 & 54 & M & Office worker \\
A16 & 64 & 0 & F & Housewife \\
A17 & 24 & 0 & F & Office worker \\
A18 & 56 & 39 & M & Office worker \\
A19 & 57 & 37 & M & Teacher \\
\hline
\end{tabular}

different levels of exposure to silica or silicate dust was performed, followed by EM microanalysis of individual particles, with the aim of finding the content of inorganic particles in BAL fluid, to investigate whether EM microanalysis of BAL fluid would detect cases of occupational exposure to silica, silicate dust, or pneumoconiosis.

\section{Materials and methods STUDY POPULATION}

Samples of BAL from 57 patients with different levels of exposure to silica or silicate dust were examined. Nineteen patients had never been occupationally exposed to silica or silicates and had only been exposed to environmental inorganic dust (group A: mean (SD) age 50.7 (15.2); 15 men, four women; 11 smokers, two ex-smokers, six non-smokers); 23 patients had been occupationally exposed to silica or silicate dust but had normal chest $x$ ray films (group B: mean (SD) age 52.0 (12.4); 22 men, one woman; 16 smokers, three ex-smokers, four non-smokers; 11 currently, 12 formerly exposed to dust); and 15 patients had had an earlier diagnosis of silicosis or coal worker's pneumoconiosis and exposure to silica or silicate

Table 2 Group B exposed to inorganic dust, withour pneumoconiosis

\begin{tabular}{llllll}
\hline $\begin{array}{l}\text { Patient } \\
\text { number }\end{array}$ & Age & $\begin{array}{l}\text { Tobacco } \\
\text { (pack-years) }\end{array}$ & Sex & Work & Exp/last * \\
\hline B1 & 69 & 0 & F & Foundry worker & $12 / 9$ \\
B2 & 58 & 0 & M & Construction worker & $40 / 0$ \\
B3 & 59 & 63 & M & Foundry worker & $22 / 1$ \\
B4 & 54 & 25 & M & Foundry worker & $27 / 1$ \\
B5 & 47 & 30 & M & Foundry worker & $23 / 0$ \\
B6 & 46 & 58 & Quarry worker & $5 / 21$ \\
B7 & 50 & 33 & M & Construction worker & $15 / 15$ \\
B8 & 56 & 78 & Construction worker & $35 / 0$ \\
B9 & 66 & 49 & M & Construction worker & $25 / 6$ \\
B10 & 40 & 23 & Foundry worker & $2 / 0$ \\
B11 & 75 & 58 & M & Paint manufacturer & $25 / 10$ \\
B12 & 56 & 78 & Construction worker & $11 / 10$ \\
B13 & 23 & 5 & M & Construction worker & $5 / 0$ \\
B14 & 58 & 82 & Lead miner & $13 / 2$ \\
B15 & 61 & 44 & M & Potter & $25 / 0$ \\
B16 & 40 & 0 & Glass manufacturer & $20 / 0$ \\
B17 & 39 & 22 & M & Potter & $22 / 0$ \\
B18 & 49 & 32 & M & Construction worker & $30 / 0$ \\
B19 & 59 & 0 & M & Construction worker & $30 / 0$ \\
B20 & 43 & 26 & Construction worker & $23 / 0$ \\
B21 & 48 & 31 & M & Foundry worker & $9 / 8$ \\
B22 & 66 & 39 & M & Construction worker & $45 / 1$ \\
B23 & 32 & 14 & Quarry worker & $5 / 3$ \\
\hline & & & &
\end{tabular}

* Duration of exposure/years since last exposure (y). dust (group C: International Labour Organisation (ILO) score equal to or higher than $1 / 1$; mean (SD) age $68.0(6.5)$ years; 14 men, one woman; eight smokers, five exsmokers, two non-smokers; zero currently, 15 formerly exposed to dust; 13 with silicosis, two with mixed dust disease with exposure to silica and silicates) (tables 1, 2, and 3).

All patients meeting the inclusion criteria (group A: environmental dust exposure; groups $B$ and $C$ : exposure to silica or silicate dust at work) and with a clinical indication for performing bronchoscopy (pulmonary nodule or haemoptysis) who were seen at a chest clinic over a nine month period were included in the study. Patients were included in groups $\mathrm{A}$ and $B$ only if the chest $x$ ray film did not show any opacity suggestive of pneumoconiosis (ILO 0/-).

Patients in group B, with a history of occupational exposure but with no interstitial lung disease, worked in a variety of occupations associated with exposure to silica or silicate dust: 10 construction workers, two quarry workers, six foundry workers, one paint manufacturer, one lead miner, two potters, and one glass manufacturer (table 2). Silicosis related to mining, quarrying, pottery, foundry, or metal working was the most common diagnosis in group C patients, two of whom were also diagnosed as having mixed dust disease (coal mining and exposure to silica or silicates in tunnel drilling) (table 3).

\section{BRONCHOALVEOLAR LAVAGE}

All subjects underwent BAL according to the European Respiratory Society guidelines. ${ }^{24}$ In brief, BAL samples were obtained from the middle lobe or lingula, with instillation of $3 \times 50$ $\mathrm{ml}$ of saline solution at $37^{\circ} \mathrm{C}$. In all cases recovery was $>40 \%$. Fluid was collected in plastic tubes and then filtered through a single layer mesh gauze. Absolute and relative cell counts of the second aliquot were carried out. The percentage of macrophages that showed pigmentation on Grünwald-Giemsa staining was also found.

\section{EM MICROANALYSIS}

Five $\mathrm{ml}$ of the second aliquot of BAL were prepared for SXM and EM microanalysis of individual particles. The organic matter was destroyed with $5 \mathrm{ml}$ of commercial bleach $(48 \mathrm{~h})$ prefiltered through $0.4 \mu \mathrm{m}$ cellulose filters (Millipore). Bleach is an effective tissue digestant and a satisfactory extraction reagent because it does not react with mineral dust. ${ }^{24}$ The solution obtained was filtered through a $0.4 \mu \mathrm{m}$ polycarbonate filter (Nucleopore). The filter was air dried in a plastic chamber, placed on EM graphite stubs, examined with a scanning electron microscope (Phillips 515), and microanalysed. Blank samples were $0.4 \mu \mathrm{m}$ polycarbonate filters washed with $5 \mathrm{ml}$ of prefiltered commercial bleach and air dried, and only showed elements present in bleach $(\mathrm{Cl})$ on SXM.

A low magnification viewing screen was selected for SXM $(\times 20.4)$ so that the entire filter could be microanalysed. The elemental 
Table 3 Group $C$ exposed to inorganic dust, with pneumoconiosis

\begin{tabular}{|c|c|c|c|c|c|}
\hline $\begin{array}{l}\text { Patient } \\
\text { number }\end{array}$ & Age & $\begin{array}{l}\text { Tobacco } \\
\text { (pack-years) }\end{array}$ & Sex & Work & Exp/last* \\
\hline $\mathrm{Cl}$ & 58 & 0 & $\mathbf{M}$ & $\begin{array}{l}\text { Coal miner } \\
\text { Tunnel driller }\end{array}$ & $\begin{array}{l}3 / 34 \\
17 / 17\end{array}$ \\
\hline $\mathrm{C} 2$ & 78 & 59 & $\mathbf{M}$ & $\begin{array}{l}\text { Coal miner } \\
\text { Quarry worker }\end{array}$ & $\begin{array}{l}7 / 51 \\
18 / 33\end{array}$ \\
\hline $\mathrm{C} 3$ & 70 & 43 & M & Metal worker & $5 / 20$ \\
\hline $\mathrm{C} 4$ & 71 & 54 & $\mathbf{M}$ & $\begin{array}{l}\text { Coal miner } \\
\text { Tunnel driller }\end{array}$ & $\begin{array}{l}15 / 29 \\
15 / 14\end{array}$ \\
\hline C5 & 65 & 0 & F & Potter & $41 / 8$ \\
\hline C6 & 60 & 43 & $\mathrm{M}$ & $\begin{array}{l}\text { Sulphur miner } \\
\text { Construction worker } \\
\text { Glass polisher }\end{array}$ & $\begin{array}{l}4 / 36 \\
10 / 26 \\
25 / 1\end{array}$ \\
\hline $\mathrm{C} 7$ & 75 & 58 & $\mathbf{M}$ & $\begin{array}{l}\text { Coal miner } \\
\text { Tunnel driller }\end{array}$ & $\begin{array}{l}30 / 20 \\
5 / 15\end{array}$ \\
\hline $\mathrm{C} 8$ & 69 & 42 & $\mathbf{M}$ & Foundry worker & $5 / 9$ \\
\hline $\mathrm{C} 9$ & 72 & 40 & $\mathbf{M}$ & $\begin{array}{l}\text { Lead miner } \\
\text { Tunnel driller }\end{array}$ & $\begin{array}{l}3 / 32 \\
2 / 30\end{array}$ \\
\hline $\mathrm{C} 10$ & 68 & 51 & $\mathbf{M}$ & Foundry worker & $15 / 10$ \\
\hline $\mathrm{C} 11$ & 59 & 40 & $\mathbf{M}$ & Quarry worker & $10 / 19$ \\
\hline $\mathrm{C} 12$ & 59 & 42 & $\mathbf{M}$ & Quarry worker & $15 / 10$ \\
\hline $\mathrm{C} 13$ & 77 & 60 & $\mathbf{M}$ & Copper miner & $15 / 25$ \\
\hline $\mathrm{C} 14$ & 70 & 53 & $\mathbf{M}$ & Quarry worker & $15 / 5$ \\
\hline $\mathrm{C} 15$ & 69 & 53 & $\mathbf{M}$ & Lead miner & $15 / 20$ \\
\hline
\end{tabular}

^ Duration of exposure/years since last exposure.

composition of all the inorganic material present on the filter was found with energy dispersive $x$ ray analysis (EDAX 9800) (working conditions: $100 \mathrm{~s} ; 20 \mathrm{KeV}$ ). In brief, all the atoms on the filter were impacted by the electron beam. The excited atoms emitted $x$ ray photons at frequencies typical for each element and the $x$ ray photons were detected by an $x$ ray spectrometer, analysed, and recorded. The profile was analysed by computer (RT-11 Digital) to calculate the detection limit (counts) of every element with an atomic number $>10$, by determining the area under the peak for the element and correcting for background concentrations. The detection limit of an element in the sample was thus a semiquantitative measurement reflecting the proportion of the sample a given element accounted for. Peak background ratio was selected to express the elemental content ${ }^{25}$ because peak/background adjusts the peak concentration of every element by the background concentration and is more accurate than $\% x$ ray counts. ${ }^{25}$

All individual particles were seen at magnifications $>1000$, and the samples of individual particles were considered suitable for EM microanalysis if there was no accumulation of particles in multilayers and the inorganic particles were clearly visible. Twenty seven subjects gave suitable samples, and in these cases particles were counted and their elemental composition was identified. When the number of particles was high 20 randomly selected particles were counted and microanalysed. In all cases the area of the policarbonate filter examined was the same $\left(\mu \mathrm{m}^{2}\right)$. Inorganic particles were identified as silica, fibrous silicates, non-fibrous

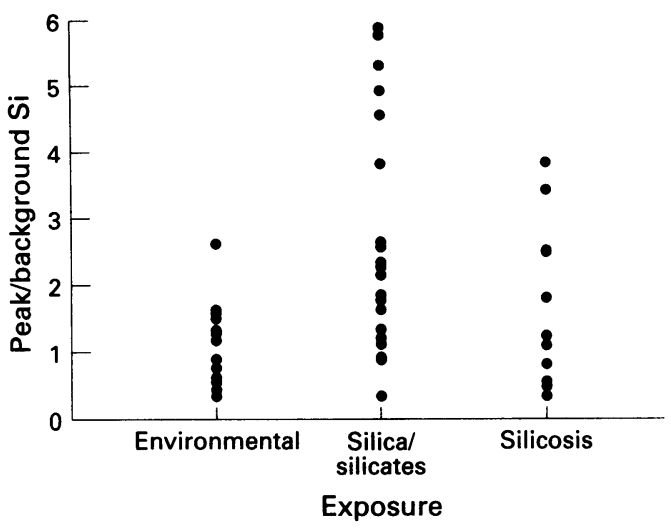

Scatter diagram of Si counts/100 s. Upper limit of normal $=1.16$ counts.

aluminium silicates, other non-fibrous silicates, or metals. Microanalysis of individual particles by EM was performed for six subjects from group A, 17 subjects from group B, and four subjects from group C. Occupational exposures in groups $B$ and $C$ were quarrying, mining, foundry work, construction work, and glass or pottery manufacture.

\section{STATISTICAL ANALYSIS}

The SAS 6.04 was used for statistical analysis. All results are expressed as means (SDs) unless specified otherwise. 95\% Confidence intervals (95\% CIs) were used for comparisons between groups. The main variable to be tested was the level of $\mathrm{Si}$ detected, expressed as peak/ background $\mathrm{Si}$, which was also the dependent variable in the multivariate analysis performed. Firstly, stepwise multiple regression was performed, with age, sex, smoking, absolute BAL cell counts, and group as independent variables, to find which variable or variables were related to level of Si detected. Because the distribution of peak/background $\mathrm{Si}$ was not normal, a logarithmic transformation of this variable was performed. A Dunnett $t$ test was used for comparisons of log peak/background Si between exposed (B and C) and control (A) groups. A second multiple regression analysis was performed with $\log$ peak/background $\mathrm{Si}$ as the dependent variable and silica, aluminium silicate, non-aluminium silicate, and metal particle counts as independent variables, to study which inorganic particles were related to the level of Si detected in BAL fluid. All the analyses were performed at a $5 \%$ significance level.

The $95 \%$ confidence interval $(95 \% \mathrm{CI})$ of peak/background $\mathrm{Si}$ in group $\mathrm{A}$ (control group) was calculated after the logarithmic transformation of the variable, and the upper limit of this $95 \%$ CI was considered to be the upper limit of normal and was used to calculate the

Table 4 Cell counts and semiquantitative $x$ ray microanalysis

\begin{tabular}{lccc}
\hline & Group $A(n=19)$ & Group $B$ (n=23) & Group $C$ (n=15) \\
\hline Cells $\left(\times 10^{3} / \mathrm{ml}\right)$ & $393(271$ to 515$)$ & $709(593$ to 826$)$ & $483(375$ to 591$)$ \\
Macrophages (\%) & $89(82$ to 96$)$ & $92(90$ to 94$)$ & $74(58$ to 91$)$ \\
Pigmented macrophages (\%) & $70(59$ to 81$)$ & $76(63$ to 89$)$ & $81(70$ to 92$)$ \\
p/b Si & $0.87(0.66$ to 1.16$)$ & $2.09(1.56$ to 2.82$)$ & $1.50(1.07$ to 2.12$)$ \\
p/b Fe & $0.93(0.44$ to 1.42$)$ & $2.41(1.05$ to 3.77$)$ & $2.63(1.23$ to 4.04$)$ \\
p/b Mg & $0.68(0.33$ to 1.02$)$ & $0.69(0.42$ to 0.97$)$ & $0.71(0.35$ to 1.07$)$ \\
p/b Al & $0.07(-0.03$ to 0.17$)$ & $0.13(0.02$ to 0.25$)$ & $0.09(-0.01$ to 0.20$)$ \\
\hline
\end{tabular}

Values expressed as means $(95 \% \mathrm{CI}) . \mathrm{p} / \mathrm{b}=$ peak/background. 
Table 5 Comparison of means for the variable log peak/background $\mathrm{Si}^{*}$

\begin{tabular}{llll}
\hline & $\begin{array}{l}\text { Difference } \\
\text { between } \\
\text { means }\end{array}$ & $(0.95 \%$ CI $)$ & $\begin{array}{l}\text { Power } \\
\text { Comparison }\end{array}$ \\
\hline B-A & 0.8735 & $(0.4224$ to 1.3246$)$ & 99.41 \\
C-A & 0.5424 & $(0.0413$ to 1.0436$)$ & 73.89 \\
\hline
\end{tabular}

* Dunnett $t$ test (group A: $n=19$; group B: $n=23$; group C $\mathrm{n}=15$ )

sensitivity and specificity of peak/background $\mathrm{Si}$ for recognising significant exposure to $\mathrm{Si}$ or silicate dust.

\section{Results}

SEMIQUANTITATIVE $x$ RAY MICROANALYSIS (SXM)

Table 4 shows the absolute cell counts in BAL fluid, relative macrophage cell counts, relative counts of pigmented macrophages, and levels of $\mathrm{Si}, \mathrm{Fe}, \mathrm{Mg}$, and $\mathrm{Al}$ detected (expressed as means ( $95 \% \mathrm{CI}$ ) peak/background), and the figure shows a scatter diagram of peak/ background $\mathrm{Si}$. To find the variables that explained the level of $\mathrm{Si}$ detected, log peak/ background $\mathrm{Si}$ was considered the dependent variable in a model with sex, age, smoking, and group as independent variables. In this multivariate analysis only the variable group was significantly related to level of $\mathrm{Si}$ detected $(P=0.003)$, such that groups $B$ and $C$ showed higher levels of $\mathrm{Si}$ detected than did group $\mathrm{A}$, with significant differences between groups B and $\mathrm{C}$ and the unexposed group (Dunnett $t$ test, table 5, figure). Introduction of absolute BAL cell count in the multivariate analysis as an independent variable did not show a significant relation between this variable and level of Si detected.

When 1.16 , the upper $95 \%$ CI of the peak/background $\mathrm{Si}$, was considered to be the upper limit of normal, the specificity of peak/background $\mathrm{Si}$ for recognising occupational exposure to silica or silicate dust was high (78.95), with acceptable sensitivity (55.6) (false positive rate 44.4 , false negative rate 21.0).

Group B was divided into two subgroups to determine if remoteness of exposure to silica or silicate dust is related to level of $\mathrm{Si}$ detected; one subgroup had current exposure to silica or silicates $(n=11)$, and the other subgroup had had no exposure over the past six months $(n=12)$. The subgroup with current exposure showed a mean peak/background $\mathrm{Si}$ of 2.19 counts ( $95 \%$ CI 1.42 to 3.40 ), which was very similar to the mean value of 2.01 counts $(95 \%$

Table 6 Individual particle EM microanalysis

\begin{tabular}{llcc}
\hline Particle counts & $\begin{array}{l}\text { Group } A \\
n=6 \text { mean }(S D)\end{array}$ & $\begin{array}{l}\text { Group } B+C+ \\
n=21 \text { mean }\end{array}$ & P value \\
\hline Silica & $1.5(1.8)$ & $8.5(5.6)$ & 0.002 \\
Nf aluminium silicates & $3.3(3.7)$ & $5.8(3.8)$ & \\
Nf non-aluminium & & & \\
$\quad$ silicates & $1.0(1.5)$ & $3.4(4.4)$ & \\
Metals & $0.7(1.2)$ & $1.1(1.4)$ & 0.0001 \\
Fibrous silicates & $0.0(0.0)$ & $0.0(0.0)$ & \\
Inorganic particles (total) & $6.5(6.9)$ & $18.8(3.8)$ &
\end{tabular}

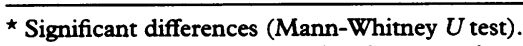

+ Groups B and C were considered as one cohort (exposed to silica or silicate dust with normal or interstitial chest $x$ ray). When the number of particles was high in the examined area 20 randomly selected particles were counted and microanalysed.

$\mathrm{Nf}=$ non-fibrous.
CI 1.26 to 3.21 ) found in the subgroup without recent exposure.

Exposed subjects (groups B and C) showed higher absolute cell counts than did nonexposed subjects (group A), with a clear difference between groups A and B (table 4). Pigmented macrophage ratios were also higher in exposed patients (groups B and C), but the difference between these and the controls (group A) was not significant when their 95\% CIs were taken into account (table 4).

EM MICROANALYSIS OF INDIVIDUAL PARTICLES Individual particles were counted and their elemental composition determined for six subjects from group $A$ and for 21 subjects from groups B and C. Because levels of Si detected by SXM were similar in the two groups of subjects (groups $B$ and $C$ ) exposed to inorganic dust they were considered as a single cohort (group $\mathrm{B}+\mathrm{C}$ ) in this part of the study (table 6).

Counts of inorganic particles were clearly lower in group A than in group B+C (table 6) and multivariate analysis showed that only silica and non-aluminium silicates entered the model and explained most of the variability of $\log$ peak/background $\mathrm{Si}\left(R^{2}=55.5 \%\right)$. Moreover, silica counts were clearly a better predictor of peak/background variability $(\mathrm{P}=0.0001)$ than were non-aluminium silicates counts $(P=0.0012)$ in the model.

\section{Discussion}

Asbestiform bodies can be easily identified in BAL fluid through an optical microscope and their counts correlate well with those in lung tissue. ${ }^{14}{ }^{15}$ Microanalysis by EM, however, provides more detailed, diagnostically useful information on the different types of nonfibrous inorganic particles present in the lower airway. ${ }^{1926}$ This approach was used by Dumortier $e t$ al to study 51 subjects who were occupationally exposed to different types of nonfibrous inorganic dust. In that study inorganic particles seen with EM were identified as silica, aluminium non-fibrous silicates, other nonfibrous silicates, and metals. ${ }^{16}$ Other studies have determined inorganic particle content of lung tissue in populations with different occupational or environmental exposures. ${ }^{27}{ }^{28}$ Relative counts of inorganic particles in BAL fluid and lung tissue have also correlated well, suggesting that EM microanalysis of BAL fluid can be used to study dust exposure. ${ }^{29}$

Our results show that SXM of BAL accurately reflects the elemental composition of occupationally inhaled inorganic dust. Levels of $\mathrm{Si}$ detected for patients in groups $\mathrm{B}$ and C, who were exposed to silica or silicate dust at work, were higher than those found for patients in group $\mathrm{A}$, who had never received such workplace exposure $(\mathrm{P}<0.05)$. A history of occupational exposure to silica or silicate dust was the only determinant of the level of Si detected in BAL fluid, expressed as log peak/background $\mathrm{Si}$, when adjusted for age, sex, smoking, and BAL cell count at the multivariate analysis. Level of Si detected can reflect both silica and silicates present in the microanalysed sample, but the EM microanalysis of individual parti- 
cles performed in our study showed that the amount of silica in BAL fluid is the main determinant of the level of $\mathrm{Si}$ detected, although non-aluminium silicate content is also relevant to a lesser degree. These two counts of inorganic particles explain most of the variability of $\log$ peak/background $\mathrm{Si}$ in BAL fluid $\left(R^{2}=55.5 \%\right)$.

Our data confirm that SXM can recognise considerable exposure to Si or silicate dust, but will not differentiate healthy exposed subjects (group B) from patients with silicosis (group $\mathrm{C})$, as shown by the lack of significant differences in log peak/background $\mathrm{Si}$ between these two groups. Group C subjects had slightly lower levels of $\mathrm{Si}$ detected, a finding that might be accounted for by either lung fibrosis or age (figure). Lusuardi et al similarly used SXM in subjects exposed and not exposed to $\mathrm{Si}$ or silicate dust to find the level of $\mathrm{Si}$ detected in BAL fluid, expressing the results as a $\mathrm{Si} / \mathrm{S}$ ratio, and found high levels in subjects with occupational exposure to inorganic dust. ${ }^{23}$ In that study the level of Si detected was different between subjects with interstitial lung disease unrelated to exposure to inorganic dust and subjects with pneumoconiosis, but as we found in our study, high values are found not only in subjects with pneumoconiosis, but also in exposed subjects without interstitial lung disease. Levels of Si in BAL fluid expressed as peak/background $\mathrm{Si}$ proved in our study to have good specificity (78.94\%) and sensitivity (55.56\%) for recognising exposure to silica or silicate dust. This finding points to the importance of first calculating peak/ background Si before performing EM microanalysis of individual particles when EM microanalysis is planned, because a positive peak/background $\mathrm{Si}$ result can easily identify unsuspected but important workplace exposure to silica or silicates.

Subjects exposed to inorganic dust recorded slightly higher cell counts and pigmented macrophage ratios than did control subjects, as is often found in people exposed to this kind of dust. ${ }^{30-32}$ Multivariate analysis did not show the absolute cell count to be a determinant of level of $\mathrm{Si}$ detected. Similarly, remoteness of exposure to dust does not seem to be related to levels of $\mathrm{Si}$ detected, as peak/background $\mathrm{Si}$ values found in patients currently exposed to dust were not significantly different from those of patients exposed in the remote past. This finding agrees with previous studies of lung dust deposition. ${ }^{29}$ Clearance of inorganic particles from the lung is very slow, and explains the persistence of inorganic particles in BAL or lung tissue over long periods. ${ }^{103-35}$

In our study, individual particle EM microanalysis specified the nature of the burden found in patients with high levels of Si. Patients exposed to inorganic dust showed high counts of inorganic particles, mainly silica particles. The multivariate analysis performed found that silica is the main determinant of the levels of $\mathrm{Si}$ found in BAL fluid. Non-aluminium silicates are also related to levels of Si detected but to a lesser degree, and are clearly not a main determinant of levels of $\mathrm{Si}$ detected. Levels of $\mathrm{Si}$ detected can therefore be considered a useful approximation of silica content of BAL fluid. Because patients in groups $B$ and $C$ had been exposed mainly to $\mathrm{Si}$ or silicate dust, however, these results cannot be extrapolated to other populations exposed to inorganic dust. Different results can be expected in patients who were occupationally exposed to metal or pure silicate dust, and in such cases EM microanalysis of individual particles will be needed to establish the precise nature of the burden. Bernstein et al used EM microanalysis of individual particles to study $\mathrm{BAL}$ samples from dental technicians and a control population of environmentally exposed subjects, and found in the technicians not only high counts of silica particles, but also a heavy burden of particles of $\mathrm{Al}$ and $\mathrm{Ni}-\mathrm{Cr}$ alloy. ${ }^{36}$

Our results confirm that EM microanalysis of BAL fluid is a useful way to study the inorganic particle content of the lower airway. When exposure to silica dust is suspected, SXM will be a useful preliminary, non-time consuming approach, because detection of a high level of $\mathrm{Si}$ is highly specific for clinically obvious exposure to silica dust and can identify clinically unsuspected cases of exposure to silica or silicate dust. The SXM must nevertheless be followed by EM microanalysis of individual particles in most cases, particularly when exposure to silicates or metal dust is suspected, because the semiquantitative approach will fail to recognise such occupational exposure.

We thank Ma Teresa Artés for her accurate statistical analysis. This work was funded partially by FISss $93 / 0105$.

1 Albin M, Johansson L, Pooley FD, Jakobsson K, Attewell R, Mitha R. Mineral fibres, fibrosis and asbestos bodies in lung tissue. Br $\mathfrak{F}$ Ind Med 1990;47:767-74.

2 Puscel K, Marten M, Dirksen M, Brinkschmidt C, Lieske $\mathrm{K}$. Asbestos screening of autopsy material. Beitr Gerichtl Med 1989;47:503-7.

3 Monsó E, Texidó A, Lopez D, Aguilar X, Fiz J, Ruiz J, et al. Asbestos bodies in normal lung of western Mediterranean populations with no occupational exposure to inorganic dust. Arch Environ Health 1995;50:305-11.

4 Monsó E, Tura JM, Pujadas J, Morell F, Ruiz J, Morera J. Lung dust content in idiopathic pulmonary fibrosis. A Lung dust content in idiopathic pulmonary fibrosis. A dispersive X ray analysis. Br f Ind Med 1991;48:327-31.

5 Churg A. Analysis of lung asbestos content. $\mathrm{Br} \mathcal{F}$ Ind $\mathrm{Med}$ 1991;48:649-52.

6 DeVuyst P, Jedwab J, Dumortier P, Vandermoten G, Vande Weyer R, Yernault JC. Asbestos bodies in bronchoalveolar lavage. Am Rev Respir Dis 1982;126:972-6.

7 De Vuyst P, Dumortier P, Moulin E, Yourassowsky N, Yernault JC. Diagnostic value of asbestos bodies in bronchoalveolar lavage fluid. Am Rev Respir Dis 1987;136:1219-24.

8 Roggli VL, Piantadosi CA, Bell DY. Asbestos bodies in bronchoalveolar lavage fluid. A study of 20 asbestosexposed individuals and comparison to patients with other chronic interstitial lung diseases. Acta Cytol 1986;30:4706.

9 Chiappino G, Friedrichs KH, Rivolta G, Forni A. Alveolar fiber load in asbestos workers and in subjects with no occupational asbestos exposure: an electron microscopy study. pational asbestos exposure: an

10 Dumortier P, De Vuyst P, Strauss P, Yernault JC. Asbestos bodies in bronchoalveolar lavage fluids of brake lining and asbestos cement workers. Br $\mathcal{F}$ Ind Med 1990;47:91-8.

11 Dodson RF, Garcia JG, O'Sullivan M, Corn C, Levin JL, Griffith DE, et al. The usefulness of bronchoalveolar lavage in identifying past exposure to asbestos. $\mathrm{Am} \mathcal{F}$ Ind Med 1991;19:619-28.

12 Sakai K, Hisanaga N, Huang J, Shibata E, Ono Y, Aoki T, et al. Asbestos and non-asbestos fiber content in lung tissue of Japanese patients with malignant mesothelioma. Cancer 1994;73:1825-35.

13 Roggli VL, Pratt PC, Brody AR. Asbestos fiber type in malignant mesothelioma: an analytical scanning electron
microscopic study of 94 cases. $A m$ F Ind Med 1993;23:605- 
14 Sebastien P, Armstrong B, Monchaux G, Bignon J. Asbestos bodies in bronchoalveolar lavage fluid and in lung parenchyma. Am Rev Respir Dis 1988;137:75-8.

15 Teschler H, Friedrichs KH, Hoheisel GB, Wick G, Soltner V, Thomson AB, et al. Asbestos fibers in bronchoalveolar $\mathrm{V}$, Thomson $\mathrm{AB}$, et al. Asbestos fibers in bronchoalveolar
lavage and lung tissue of former asbestos workers. $\mathrm{Am} \mathcal{f}$ Respir Crit Care Med 1994;149:641-5.

16 Dumortier P, De Vuyst P, Yernault JC. Non-fibrous inorganic particles in human bronchoalveolar lavage fluids. Scanning Electron Microscopy 1989;3:1207-18.

17 Gaudichet A, Pairon JC, Malandain O, Couste B, Brochard $P$, Bignon J. Etude minéralogique des particules nonfibreuses du liquide de lavage broncho-alveolaire. Rev Mal Respir 1987;4:237-43.

18 De Vuyst P, Dumortier P, Léophonte P, Vande Weyer R, Yernault JC. Mineralogical analysis of bronchoalveolar lavage in talc pneumoconiosis. Eur $\mathcal{F}$ Respir Dis 1987;70:1506 .

19 Johnson NF, Haslam PL, Dewar A, Newman-Taylor AJ, Turner-Warwick $M$. Identification of inorganic dust particles in bronchoalveolar lavage macrophages by energy dispersive $x$ ray microanalysis. Arch Environ Health 1986;41:133-44.

20 Brody AR, Vallyathan NV, Craighead JE. Distribution and elemental analysis of inorganic particulates in pulmonary tissue. Scanning Electron Microscopy 1976;3:477-82.

21 Pairon JC, Roos F, Iwatsubo Y, Janson X, Billon-Galland $\mathrm{MA}$, Bignon J, et al. Lung retention of cerium in humans. Occup Environ Med 1994;51:195-9.

22 Funahashi A, Schlueter DP, Pintar K, Siegesmund KA Value of in situ elemental microanalysis in the histologic Value of in situ elemental microanalysis in
diagnosis of silicosis. Chest 1984;85:506-9.

23 Lusuardi M, Capelli A, Donner CF, Capelli O, Velluti G. Semi-quantitative $x$ ray microanalysis of bronchoalveolar lavage samples from silica-exposed and non-exposed subjects. Eur Respir f 1992;5:798-803.

24 European Society of Pneumology Task Group on BAL. Technical recommendations and guidelines for bronchoalveolar lavage (BAL). Eur Respir f 1989;2:561-85.

25 Wroblewski R, Wroblewski J, Roomans GM. Low temperature techniques in biochemical microanalysis. Scanning Electron Microscopy 1987;1:1225-40.
26 Bellis D, Belluso E, Burlo P, Ferraris G, Fubini B, Volante $\mathrm{M}$, et al. An etiological definition of a case of mixed pneumoconiosis due to silicates and coal in the absence of anamnesic data. Med Lab 1994;85:122-33.

27 Abraham JL, Burnett BR, Hunt A. Development and use of a pneumoconiosis database of human pulmonary inorganic particulate burden in over 400 lungs. Scanning Electron Microscopy 1991;5:95-108.

28 Stettler LE, Platek SF, Riley RD, Mastin JP, Simon SD. Lung particulate burdens of subjects from the Cincinnati, Ohio urban area. Scanning Electron Microscopy 1991;5:8594.

29 Chariot P, Couste B, Guillon F, Gaudichet A, Bignon J, Brochard P. Nonfibrous mineral particles in bronchoalveolar lavage and lung parenchyma from the general population. Am Rev Respir Dis 1992;146:61-5.

30 Begin RO, Cantin AM, Boileau RD, Bisson GY. Spectrum of alveolitis in quartz-exposed human subjects. Chest 1987; 92:1061-7.

31 Begin R, Cantin A, Sebastien P. Chrysotile asbestos exposures can produce an alveolitis with limited fibrosing activity in a subset of high fibre retainer sheep. Eur Respir $\mathcal{F}$ activity in a subse

32 Rom WN. Relationship of inflammatory cell cytokines to disease severity in individuals with occupational inorganic dust exposure. Am F Ind Med 1991;19:15-27.

33 Muggenburg BA, Boecker BB, Diez JH, Snipes MB. Observations on the lung retention of inhaled, relatively insoluble, environmentally-related particles. Chest $1981 ; 80$ : 19s-21s.

34 Begin R, Sebastien P. Excessive accumulation of asbestos fibre in the bronchoalveolar space may be a marker of individual susceptibility to developing asbestosis: experimental evidence. Br f Ind Med 1989;46:853-5.

35 Begin R, Massé S, Sebastien P, et al. Sustained efficacy of aluminium to reduce quartz toxicity in the lung. Exp Lung Res 1987;13:205-22.

36 Bernstein M, Pairon JC, Morabia A, Gaudichet A, Janson $X$, Brochard $P$. Non-fibrous dust load and smoking in dental technicians: a study using bronchoalveolar lavage. Occup Environ Med 1994;51:23-7.

\section{Rejected manuscripts}

From February 1994, authors whose submitted articles are rejected will be advised of the decision and one copy of the article, together with any reviewer's comments, will be returned to them. The fournal will destroy remaining copies of the article but correspondence and reviewers' comments will be kept. 